\title{
KONSEP PLURALISME AGAMA MENURUT DJOHAN EFFENDI
}

\section{CONCEPT OF RELIGIOUS PLURALISM ACCORDING TO DJOHAN EFFENDI}

\author{
Rif'at Husnul Ma'afi ${ }^{1}$, Alvin Qodri Lazuardy ${ }^{2}$ \\ Universitas Darussalam Gontor (UNIDA) $)^{1,2}$ \\ rifathaem@gmail.com ${ }^{1}$, alvintheology@gmail.com ${ }^{2}$
}

\begin{abstract}
ABSTRAK
Pluralisme Agama adalah paham yang menyakini tidak ada agama yang yang paling benar, semuanya sama karena setiap Agama menuju Tuhan yang Maha Esa. Permasalahan dalam kemajemukan Agama terkadang menjadi konflik pertumpahan darah. Agama dituduh sebagai penyebab utama dalam konflik. Dikarenakan Agama mempunyai konsep yang berbeda-beda. Kemudian didukung dengan situasi kehidupan di Indonesia sangat majemuk. Maka diusunglah gagasan tersebut menjadi proyek besar dalam gerakan Postmodernisme. Dalam pandangan Islam paham Pluralisme Agama adalah paham merusak Aqidah, Syariah dan Akhlak Islam. Berangkat dari masalah ini, Peneliti bertujuan untuk mengetahui Inti dari paham Pluralisme Agama dalam konteks Indonesia. Dalam penelitian ini, peneliti menggunakan pendekatan Teologis, Filosofis dari kedua pendekatan merupakan bagian dari kajian pustaka. Kemudian peneliti menggunakan Metode Deskriptif untuk mengetahui tentang Pluralisme, makna Agama, sejarah perkembangannya dan pengaruhnya dalam masyarakat Indonesia. Dan penelitian menggunakan metode analisis dan kritik untuk menganalisa paham tersebut pandangan para tokoh Islam.Dari pembahasan ini, peneliti memfokuskan pada pemikiran Djohan Effendi tentang Pluralisme Agama. Dalam pemikiranya ia mengusung ide Teologi Kerukunan yang didalamnya pertemuan titik-titk temu Agama, memaknai Agama hanyalah hasil dari lingkungan dan bersifat nisbi, meyakini manusia tidak akan pernah mencapai pengertian Agama sesunguhnya, menafsirkan ayat-ayat Alquran sebagai landasan Pluralisme Agama seperti kebebasan beragama.
\end{abstract}

Kata Kunci: Pluralisme, Agama, Kebebasan, Nisbi, Teologi Kerukunan

\section{INTRODUCTION}

Religious pluralism is an ideology that claims that all religions are equally true because every religion goes to God Almighty. Problems in religious pluralism are sometimes regarded as the conflict of bloodshed. Religion is accused of being the main cause. It is due to the Religion has different concepts. It occurs almost worldwide, this 
understanding is growing rapidly in Indonesia with the support of the life situation in Indonesia that is very diverse. In Indonesia, Religious Pluralism ideology initiated by many prominent persons of Indonesian Liberal, one of them is Djohan Effendi, he considered Religious Pluralism as a major project in Postmodernism movement. $\mathrm{He}$ believed that only by the Religious Pluralism, problem conflicts between religious would be controlled. Nevertheless, in Islamic view with the ideology of Religious Pluralism is an ideology that destroys Aqeedah, Sharia and Islamic Ahlaq.

Referring to the above problems, the problems of Religious Pluralism are very important to discuss, because the idea is not in accordance with Islam. The researcher aimed to find out the essence of the ideology of Religious Pluralism in the context of Indonesia then explained the Islamic attitude towards the ideology.

\section{Meaning and Definitions of Religious Pluralism}

Before heading to the definition of pluralism, let us elaborate again the origin of the word of pluralism, of which there are three sequences that lead to the Pluralism namely the Plural, Plurality and become Pluralism. The word "Pluralism" is derived from the word of plural which means plural, more than one. In the Great Dictionary of Indonesian, Pluralism has meaning as a condition of a pluralistic society by having various differences. Plurality is a fact that in a particular country or region, there are differences and mutual respect ${ }^{1}$,

Definition of Pluralism in the church has two definitions: first, a term for people who have more than one office in the ecclesiastical structure, second, person who holds more than one office simultaneously, both are in ecclesiastical and nonecclesiastical $^{2}$,

\footnotetext{
${ }^{1}$ Adnin Armas, Pluralisme Agama Telaah Kritis Cendikiawan Muslim (Jakarta: INSIST, 2013/1434), xiii

2 Anis Malik Thoha, Tren Pluralisme Agama: Tinjauan Kritis (Jakarta: Prespektif
} 
The above definition is also in line with what was raised by Djohan Effendi in his book "Pluralism and Freedom of Religion" that is, Pluralism is the appreciative perspective and approach in facing the heterogeneity of a society whose citizens made up of different ethnic groups, races, religions and societies that accept, appreciate, encourage participation and development of traditional culture as well as their specific interests in the sphere of life together ${ }^{3}$.

From the explanation above, the researcher took the definition that Pluralism has three elements, namely plural, tolerance, peace by finding the connecting points of the various ideology, though to break through the exclusive barriers on each of Religion and based on Humanism ${ }^{4}$.

Kelompok Gema Insani, cetakan pertama, 2005), 11

3 Djohan Effendi, Pluralisme dan Kebebasan Beragama, (Sleman: Institut DIAN/Interfidei, 2015), 5

${ }^{4}$ Humanisme adalah Aliran yang bertujuan menghidupkan rasa perikemanusiaan dan mencita-citakan pergaulan hidup yang lebih baik, lihat Kamus Besar Bahasa Indonesia (Surabaya : 2006 Yoshiko Press), 289

\section{Biography of Djohan Effendi}

Djohan Effendi was born in October 1939, son of Haji Mulkani and Hajjah Siti Hadijah ${ }^{5}$ in the small town of Kandangan, South Kalimantan. His Mother and Father are the native of Banjar and work in Kandangan as small traders.

In 1957 at the age of 17, he moved out to Yogyakarta to participate in the study of Islamic law in the State Islamic Justice Education $\quad(\mathrm{PHIN}){ }^{6} \quad$ Religion comparison subjects attracted Djohan Effendi's attention because he could learn about other religions. Likewise, the philosophy subject that gave Djohan new insight into the way of thinking fundamentally. His philosophy teacher, Hasbullah Bakry, inadvertently making Djohan acquainted with the Library of Ahmadiyah. Djohan did not have time to go deeper into the teachings of Ahmadiyah because of his studies in PHIN of Yogyakarta has been completed (1960) and he had to

\footnotetext{
${ }^{5}$ Gaus Ahmad, Sang Pelintas batas Biografi Djohan Effendi ( Jakarta: ICRP 2009, cetakan pertama), 1

${ }^{6}$ Greg Barton. op.cit., 176
} 
return to Kalimantan. ${ }^{7}$ Important changes also involved in the world of PERSIS since he became acquainted with Ustadz Said bin Thalib of Ulama Liberal of PERSIS, from that, Djohan's perspective about Liberal began to appear at the ways of his thinking. ${ }^{8}$

Then in 1963 Djohan was sent again to Yogyakarta by the Ministry of Religious Affairs as the task student of studying for taking college in the Faculty of Sharia of IAIN Sunan Kalijaga, Yogyakarta. Obviously, Djohan Effendi was a very diligent student in repeating Thought of Ahmadiyya (both doctrines of Lahore and Qodiyan) and was inspired by Muhammad Iqbal with his thinking in the world of Neo-Modernism ${ }^{9}$.

In 1973, Djohan Effendi was promoted to Private Staff member of Minister of Religious Affairs, a position held until 1978. In 1997 he became head of the Sub-Directorate of Religious University, to 1981.

\footnotetext{
${ }^{7}$ Gaus Ahmad, op.cit., 49

${ }^{8}$ Ibid., 42

${ }^{9}$ Greg Barton. op.cit., 178
}

From 1981 to 1983 he was Head of the Research Institute of Religion and Society. Finally, in 1987 he served as aide of Minister Assistant/Secretary of State for Special Affairs in the Department of Research and Development. ${ }^{10}$ Since Late in the 1980s Djohan Active in initiating dialogues between religion. Theology of harmony that had been talked about since becoming Religion Department staff, met with notions of inclusiveness of Islam that has been regarded by Gusdur and Cak Nur. Success of Minister of Religious Affairs, Ali Mukti in the 1970s in a religious dialogue trying to be revived by figures outside the administration. In the early 1990s, Theology of Religious Pluralism and Inclusivism began to be turned on again by the Liberal figures. The claim of most correct Religion and the other one is regarded as wrong were signalled by the suspicion among followers of other religions. ${ }^{11}$

\footnotetext{
${ }^{10}$ Greg Barton. op.cit., 195

11 Gaus Ahmad, Sang Pelintas batas Biografi Djohan Effendi (Jakarta: ICRP 2009), 164-165
} 


\section{RESEARCH METHODS}

This research uses library approach (library research), which is a series activities consisting of methods library data collection, reading, record and process ingredients research.

This research is qualitative, namely research which aims to present a holistic discussion contextual way collect data naturally and make researchers as data collection instruments.

\section{RESULT AND DISCUSSION}

\section{Religious Pluralism According to} Djohan Effendi

Initiating into the core of Religious Pluralism then elaborate the meaning of Plurality and Pluralism which has one lane of mutual attachment and interconnected. Plurality is a necessity that must be sought in the context of positive activities and towards the common good. Pluralism is meant as an ideology and principle values that give direction to how to follow, understand, receive, and manage the fact that is called as plurality so that it does not become a negative factor but to make a positive factor in the life of a pluralistic society. ${ }^{12}$

Thus, Pluralism must be implemented wholeheartedly and with ideas that leads to Peace. Furthermore, the researcher will describe three basic ideas of Djohan Effendi in Religious Pluralism among others, first, Theology of harmony, second, Relative Humans in view of religion, and third, religious freedom.

\section{Religious Freedom}

Human rights are inherent in freedom, one human's freedom is freedom of religion, with this foundation, Pluralism thought of Djohan Effendi encouraged to practice it.

In human life, there must be a sovereign foundation without any intervention, one of them is freedom of religion, freedom of religious conversion, freedom to follow the

12 Djohan Effendi, Islam dan Pluralisme, (Sleman: Interfidei cetakan ke-3, 2017), viii 
sect or doctrine of religion and even the freedom of the human rights perspective is complete freedom. Because the freedom that accompanied the requirements is no longer a freedom. The only requirement that can be accepted is that freedom should not infringe on the freedom of others. ${ }^{13}$

One reason they objected to full and intact religious freedom is that of religious freedom in Indonesia based on the principle of God. Precisely because our country is based on the principle on God, so the state is obliged to guarantee the freedom that was given to humans in the area of Republic of Indonesia, determine their beliefs, whether religious, belief, or whatever they are called. A state has no researcherity in deciding which religion will be embraced and which ones should not be adopted. Only with full and intact religious freedom, sincere diversity would give meaning to human life. All forms of coercion, subtle or

13 Djohan Effendi, Pluralisme dan Kebebasan Beragama, op.cit., 86 disguised, will only give birth to hypocrisy. ${ }^{14}$

Tolerance of differences in beliefs are values and virtues that generate acceptance and respect for the existence of others. Because the true Tolerance, of course, does not stop at the mere recognition of the existence of others who hold different beliefs, perhaps contrary to the beliefs we profess, but also requires commitment and effort to walk arm in a spirit of togetherness and equality. Even more than that, we must honour and allow freedom of others to believe and perceive faith of their choosing, as we believe and live the faith that we profess. Public attitudes are derived from what has been recognized as the "golden rule", and this is what is taught in all religions of the world ${ }^{15}$

The researcher responded to the statement of Djohan in the first paragraph, in this case, it is highly visible patterns of Djohan's thought that is very Humanist because, in

\footnotetext{
${ }^{14}$ Ibid 87

15 Djohan Effendi, Pluralisme dan Kebebasan Beragama, op.cit., 96-97
} 
response to religion, he was again using pure reason of human, all the freedom are inhuman even though he converted religions, adheres to any sect is absolute freedom of human with one condition that does not interfere with the freedom of others.

Furthermore, in the second paragraph, it seemed that Djohan used the arguments of Pancasila as the foundation of freedom that is full and complete, which means is the first principle of God, it is very clear that the state has no researcherity to regulate the religion for its inhabitants because only God that is absolutely true, then human beings are free to embrace any religion. And he argued that if the first principle revealed one supreme divinity, it means that if there is a conviction or belief that is not based on the one almighty God then he has no place in this country, obviously this is not what they want. Then by maintaining the idealism of humanism, he supported freedom of religion by people who do not have religion, but the state does not regulate the Human
Rights of those to have religion or not.

According to Rois Amm Nahdhotul Ulama (NU) K.H. Ahmad Siddiq gave his opinions, he said, "The word "Almighty" on the first principle that is belief in one God is regarded as the balance of the seven words that are removed from the first principle according to the original formulation, Formulation of "Belief in the almighty One" reflects the meaning of Monotheism (pure monotheism) according to the Islamiyah faith (Surah of Al-Ikhlas), if the other religions can receive it, then we give thanks and pray". ${ }^{16}$

From the opinion of Rois Amm N.U, it is clear that what is the meaning of the Almighty is referring to the only one God.

Then in 1983 held National Conference of Ulama' NU in Situbondo exactly on December 21, decided on a declaration on the Relationship of Islam and Pancasila, namely: First, Pancasila as the basic

\footnotetext{
${ }^{16}$ Adian Husaini, Pancasila Bukan Untuk Menindas Hak Konstitusional Umat Islam, (Depok: Gema Insani Press, cet.ketiga, 2017), 138
} 
philosophy of the state, and is not a religion and can not take the place of religion. Second, the principle of "Almighty God" as the basis for the Unitary State of the Republic of Indonesia, according to article 29 paragraph 1 of the Act of 1945, which animates the other principles, reflecting the views of monotheism in Islam. Third, for Nahdhotul Ulama Islam is Aqeedah and Shariah, covering aspects of hablumminallah wa hablumminannas. Fourth, the Reception of Pancasila and its practice is a form of Muslims in carrying out Islamic law. Fifth, As a consequence of the above attitude, NU obliged to keep and secure the correct understanding and the pure experience and consistent by all parties. ${ }^{17}$

The researcher considered that from the National Conference of Ulama N.U in 1983, the Muslims take a clear and unambiguous attitudes, attitudes of Islam in interpreting the God Almighty is with Monotheism in Islam. And

${ }^{17}$ Ibid, 145
Monotheism here refers to the One and Only Allah SWT. In short, the first principle contained the main teachings of Islam that is monotheism.

Then stressed by General Chairman of MUI in 1976, Prof. Hamka explained the meaning of God Almighty, there is one who has the opinion that God in Pancasila and the Act of 1945 is not God taught by religion, there is also one who interpreted it as the source of the soul of Indonesia, these interpretations seemed to have tarnished the religious, as if God and religious teachings should not participate in the governance of state law. But it flies in the opening of the Act of 1945 , it is clearly written: "on the grace of God". Then the above interpretations seemed to be null and void because the true God in Pancasila and the Act of 1945 is Allah wahdahu. ${ }^{18}$

In Islam, receive the freedom of religion, not to impose to convert

${ }^{18} \mathrm{Ibid}, 149-150$ 
to Islam ${ }^{19}$ and Islam recognizes other religious diversity in the social world. ${ }^{20}$ It must be emphasized also that Islam does not recognize the truth of other religions as Islam exclusively. $^{21}$

So Islam gives freedom of religion because Islam does not force people to enter Islam, and Islam have an attitude of tolerance without acknowledging the truth of other religions but recognizes diversity.

In the book the National State of Pancasila, Dr Kaelan provided an explanation of Actual Value on God in social life, he stated as follows. In life tolerance between religious communities in the country of Indonesia, it is guaranteed in the state Constitution, namely freedom of religion is guaranteed by the Constitution of the Republic of Indonesia in 1945, as the amendment results of Article 28 E which revealed:

Paragraph (1), "Everyone is Free to embrace religion and

\footnotetext{
${ }^{19}$ QS. Al-Baqarah: 256

${ }^{20}$ QS. Hud: 118

${ }^{21}$ QS. Al-Kafiruun: 1-6, Baca juga: Hamka, Pelajaran Agama Islam, op.cit., 62
}

worship according to his religion, to choose education and teaching, choosing a job ... Paragraph (2), "Everyone has the right to freedom of belief to believe, expressing an attitude, in accordance with his conscience.

And Article 29 which revealed:

Paragraph (2), "The State guarantees the freedom of each citizen to profess his own religion and to worship according to his religion and belief'. ${ }^{22}$

After discussing about the error of Djohan Effendi of understanding of God Almighty and Religious Freedom with the pattern of Liberty that is far from the original value of Pancasila, and he also gave an opinion on Tolerance, that tolerance means to accept, acknowledge the truth of other religions to a degree, he admitted the truth of other religions equal to acknowledge the truth of religion itself, this is based on his statement in the third

\footnotetext{
${ }^{22}$ Kaelani, Negara Kebangsaan Pancasila, Kultural, Historis, Filosofis, Yuridis dan Aktualisasinya, (Yogyakarta: Paradigma, 2013), 218
} 
paragraph. It seems that Understanding of Djohan Effendi in Inter-Religious Tolerance is different from the understanding that has been outlined by the Indonesian Ulama Council of the People of Islam.

Indonesian Ulama Council has taken the attitude of tolerance towards the tolerance polemic. In this explanation, the researcher will give a presentation of the Concept of Tolerance in the correct foundation by the Indonesian Ulama Council.

Tolerance in Arabic means "tasamuh", "ihtimal", which means it gracefully, or in Latin, tolerantie means patients of heart, heart patients if something is unsatisfied. In general, tolerance is regarded as granting of freedom to his fellow human beings to uphold their beliefs, without disturbing the freedom of others by not violate the norms that exist. $^{23}$

In the concept of Tolerance of Islam, it is diametrically opposed to

\footnotetext{
${ }^{23}$ Umar Hasyim, Toleransi dan Kemerdekaan Beragama Dalam Islam Sebagai Dasar Menuju Dialog dan Kerukunan Antar Agama, (Surabaya: Bina Ilmu, 1979), 22
}

the Tolerance offered by Djohan Effendi, according Abas Mansur Tamam in his book of Islamic Worldview Paradigma Intelektual Muslim, Although Tolerance has the meaning of "facilitate" but it does not mean ignoring the main principles of the religion, as well as branches. Because it does not mean the merged attitude of the contrary doctrine to Islam. Because Islam is decisive, not lost their identity, especially if only follow other religion or another culture. ${ }^{24}$

In this case, the researcher gave the opinion that Tolerance means "facilitate" by no means mutually facilitate without limit, so it destroys identity in Islam. In Islam, has a fundamental principle cannot be -negotiable, it does not mean that Islam does not accept another religion and another doctrine. Islam recognizes diversity and to love all human beings.

Then it was reaffirmed in the book of The Problem of Religious

\footnotetext{
24 Abbas Mansur Tamam, Islamic Worldview Paradigma Intelektual Muslim, (Jakarta: Spirit Media, cet.ke-2, 2017), 142
} 
Pluralism, published by CIOS UNIDA Gontor ${ }^{25}$, Islam is the certain religion, seeing human beings as a whole human being, and return all affairs to Allah and His Messenger, then the tolerance of Islam is set in the Worldview of Islam itself, by believing that Islam is certain that is submitted from the Prophet to the Human. ${ }^{26}$ But also commanded to love our fellow human beings ${ }^{27}$. Islamic Tolerance can be regarded as a tree whose roots are consistently strengthened branches, twigs and fruit then give mercy to all human beings. ${ }^{28}$

Then in implementing Tolerance, it must be well regulated and settled in accordance with the lines of Islam in Indonesia or there are particular aspects of the tolerance namely: First, Recognizing the Rights of others as an attitude of granting freedom to others without violating the rules. Second, respect the beliefs of others, respect for the Foundation of strong Aqeedah and

${ }^{25}$ Adib Nuriz dkk, op.cit., 110

${ }^{26}$ QS. Al-Baqarah: 147

27 QS. Al-Mumtahanah: 8

${ }^{28}$ QS. Ibrahim: 8 does not impose to get in on one class. Third, Recognizing the difference is the principle that was stated by Mukti Ali, he did not need to make a principled distinction hostility. Fourth, understand each other will not create any harmony without mutual understanding by not violating existing norms. Fifth, awareness and honesty to recognize and acknowledge difference to the unity of consciousness of every human being. Sixth, making Pancasila alive which was designed on the basis of monotheism and made order in Indonesia. ${ }^{29}$

So the researcher considered that concepts of tolerance in the Islamic view is very consistent and does not hurt the understanding of other religions, Islam must maintain its own identity with monotheism, but in communicating with the entire human, it needs to love each other in the nature of humanity. From the explanation in the view of Islam, the

\footnotetext{
${ }^{29}$ Umar Hasyim, Toleransi dan Kemerdekaan Beragama Dalam Islam Sebagai Dasar Menuju Dialog dan Kerukunan antar Agama (Surabaya: Bina Ilmu, 1979), 23-25
} 
attitude of the researcher of the notion of Djohan Effendi about tolerance is refused. This attitude is based on the previous explanation.

The researcher considered that the foundation of Djohan's thought on religious freedom seems to be two points in its foundations, namely: the principles on God and Tolerance, with this second foundation, it will be implemented the Freedom of religion, but the second foundation does not correspond to its original meaning so as to not reflect the freedom of religion in accordance with Islam. The freedom of religion in Islam is illustrated as follow.

\section{Sheikh Yusuf Al-Qordhowi} provided an explanation of human Freedoms, one of which is the Freedom of Religion. Among the rights of human freedom is the freedom of religion. Freedom of religion in Islam is that the freedom with belief and freedom of worship, Islam does not accept the treatment of people who force others to abandon their religion $^{30}$ that is

\footnotetext{
${ }^{30}$ QS. Al-Baqarah: 256
}

adopted and that is believed by them. In Qur'an, it confirmed that there is no compulsion to convert to Islam and did not force all people to embrace Islam $^{31}$. It should be underlined that this freedom is freedom with faith, not freedomoriented on western thought which stems from the liberation of France. In Islam, this freedom was not oriented to the Liberation of France, but freedom in leaning on the Islamic view. $^{32}$

From the explanation of Yusuf Al-Qordhowi on Religious Freedom, it is highly visible the hospitality of Islam against non-Islamic religion. Islam does not force other people to enter in Islam but on the other side, Islam upholds human affection. The researcher argued that Religious Freedom in Islam is reasonable freedom and having a faith, not freedom that is oriented to the western. From the above explanation,

\footnotetext{
${ }^{31}$ QS. Yunus: 99

32 Yusuf Al-Qardhawi, Malamih AlMujtama' Al-Muslim Alladzi Nansyuduhu, Translated by Setiawan Budi Utomo, Anatomi Masyarakat Islam (Jakarta: Pustaka Al-Kautsar cetakan-2, 2000), 113-114
} 
the researcher's attitudes toward religious freedom according to Djohan Effendi is refused, which is based on the previous explanation.

\section{CONCLUSION}

From the above explanation, it can be concluded that Djohan Effendi is one of the leaders of the Liberal Islam Indonesia because his thoughts are contrary to the concept of Islam. Of the three figures, Theology of harmony, Human Relative in Religion and Religious Liberty, he believed that in Theology of harmony of all religions should be met in a connecting point and merged into social ethics in society but this is refuted by the arguments of Islamic figures presented by the researcher, that basically there will be no connecting point of religion because in terms of history is different and every religion has a belief they hold. Furthermore, in the Relative Human thought of religion, Djohan Effendi stated in Surah of AlFatihah verse "Ihdinash-sh-shirotol Mustaqim" that human is relative in believing in any religion then other religion thus becomes Relative, there is no truest religion, but this is indisputable by Muslim leaders that the researcher explained that the intent of Relative is human because human is in a dimension of limitations, whereas the religion was not going to be Relative because religion was from God delivered by the angel to the human. And something that comes from God will not be Relative, and it must be Absolute. Moreover, in religious freedom Djohan believe that we are free to choose any religion and there is no compulsion in it, this opinion is disproved by the researcher by referring to the opinion of the leaders of Islam, freedom of religion actually is viewed in the context of when the children of nazir are mostly Jews, then the apostles gave preference to them that in Islam there is no compulsion into it but there will be reckoning of God one day later if there is already guidance coming but even reject it. Referring to that, Religious Pluralism is the lost ideology that wants to merge the meaning of religion into one and is destructive in Islam because Islam is 
a certain religion and the only religion blessed by Allah. And obviously the attitude of Islam towards Religious Pluralism is strongly rejected, it is proved to the issuance of MUI's fatwa that forbids the ideology of Religious Pluralism.

\section{REFERENCES}

AF, Gaus Ahmad, 2009, Sang Pelintas Batas - Biografi Djohan Effendi, Indonesian Conference on Religion and Peace (ICRP), Jakarta

Al-Anshori, Fauzan, 2003, Melawan Konspirasi Jaringan Islam Liberal (JIL), Pustaka Al-Furqan, Jakarta

Al-Qardhawy, Yusuf, 2000, Anatomi Masyarakat Islam, Jakarta, Pustaka AlKautsar

Amrullah, Abdul Malik bin Abdul Karim, 1965, Tafsir AlAzhar, Jilid 15, $\mathrm{H}$. Abdulkarim - $\mathrm{H}$. Achmad Syafei, Surabaya
1988, Tasauf Moderen, Pustaka Panjimas, Jakarta

1996, Pelajaran Agama Islam, Bulan Bintang, Jakarta , 2001, Tafsir Al-Azhar, Jilid1, Pustaka Nasional Pte Ltd, Singapura , 2001, Tafsir Al-Azhar, Jilid 5, Pustaka Nasional Pte Ltd, Singapura

Armas, Adnin, dkk, 1434, Pluralisme Agama Telaah Kritis Cendekiawan Muslim, INSISTS, Jakarta

Barton, Greg, 1999, Gagasan Islam Liberal di Indonesia Pemikiran NeoModernisme Nurcholish Madjid, Djohan Effendi, Ahmad Wahib, Abdurrahman Wahid, Pustaka Antara, Jakarta

Effendi, Djohan, 2010, Pembaruan Tanpa Membongkar Tradisi, Bogor, Grafika Mardi Yuana , 2012, Pesan-pesan AlQuran Mencoba Mengerti Intisari Kitab Suci, Serambi Ilmu Semesta, Jakarta 


2015, Menimba
Pelajaran dari Berbagai
Agama dan Keyakinan,
Interfidei, Yogyakarta
, 2015, Pluralisme dan
Kebebasan Beragama,
DIAN/Interfidei,
Yogyakarta
, et al, 2017, Islam dan
Pluralisme Agama,
Interfidei, Yogyakarta

Hasyim, Umar, 1979, Toleransi dan Kemerdekaan Beragama dalam Islam Sebagai Dasar Menuju Dialog dan Kerukunan Antar Agama, Bina Ilmu, Surabaya

Hick, John, 2006, translator; Ma'ruf, Amin, Aminuddin, Taufik, Tuhan Punya Banyak Nama, DIAN/Interfidei,

Yogyakarta

Husaini, Adian, 2005, Islam Liberal, Pluralisme Agama \& Diabolisme Intelektual, INSISTS \& Risalah Gusti, Surabaya , 2009, Pancasila Bukan Untuk Menindas Hak Konstitusional Umat Islam - Kesalahpahaman terhadap Pancasila
1945-2009, Gema Insani, Jakarta

, 2015, Liberalisasi Islam di Indonesia Fakta, Gagasan, Kritik dan Solusinya, Gema Insani, Depok

Jamaludin, Adon Nasrullah, 2015, Agama dan Konflik Sosial - Studi Kerukunan Umat Beragama, Radikalisme, dan Konflik Antarumat Beragama, Pustaka Setia, Bandung

Jurnal Kalimah, Vol. 11, 2013, UNIDA Press, Ponorogo

Kaelan, 2013, Negara Kebangsaan Pancasila - Kultural, Historis, Filosofis, Yuridis, dan Aktualisasinya, Paradigma, Yogyakarta

Muslih, Kholid, dkk, 2018, Worldview Islam : Pembahasan Tentang Konsep-konsep Penting dalam Islam, UNIDA Gontor Press, Ponorogo

Nata, Abuddin, 2014, Metodologi Studi Islam, Raja Grafindo Persada, Jakarta 
Nazir, Moh, 1983, Metode bersama Missionaris,

Penelitian, Ghalia Indonesia, Jakarta

Orientalis dan

Kolonialis, Center of

Islamic and Occidental

Nuriz, Adib Fuadi, dkk, 2015, Problem Pluralisme Agama : dan Dampaknya Studies (CIOS), Ponorogo terhadap Kehidupan Sosial Keagamaan, CIOS, Ponorogo

Puar, Yusuf Abdullah, 1978, Muhammad Natsir 70 Tahun Kenang-kenangan Kehidupan dan Perjuangan, Jakarta, Pustaka Antara

Schuon, Frithjof, 2003, Mencari Titik Temu Agama-agama, Pustaka Firdaus, Jakarta

Sjafril, Akmal, 2017, Buya Hamka Antara Kelurusan 'Aqidah dan Pluralisme, Afnan Publishing, Bogor

Tamam, Abas Mansur, 2017, Islamic Worldview Paradigma Intelektual Muslim, Spirit Media, Jakarta

Thoha, Anis Malik, 2005, Tren Pluralisme Agama : Tinjauan Kritis, Perspektif, Depok

Zarkasyi, Hamid Fahmy, 2008, Liberalisasi Pemikiran Islam - Gerakan 